\title{
The Role of General Background in the Success of ESP Courses: Case Study in Iranian Universities
}

\author{
S. Mohammad Hosseini Maasum \\ Department of English Language, Payame Noor University, Iran
}

\begin{abstract}
The success of Language courses has long been a great concern for ELT specialists. This has specially worried teachers in ESP classes where English is a means rather than an end. One of the major questions concerning ESP is the way it is different from and influenced by General English. This study was mainly concerned with the relationship between GE and ESP in two groups of subjects (English and non-English majors). Each group was given a GE test and an ESP test. The results of the two tests were, then, correlated. For non-English Majors, componential scores (of Grammar, Vocabulary, and Reading) were also correlated. The analysis showed that GE and ESP had a highly positive correlation in both groups, and also in non-English majors the components of the two tests had highly positive correlations. Additional analyses (t-tests), however, indicated that while non-English majors performed significantly better in ESP than in GE test, English Majors performed significantly better in GE than in ESP.
\end{abstract}

\section{Introduction}

With the technological developments in the modern world, the transfer of knowledge has turned to be a vital concern. Traditionally, the most technologically advanced countries, which produce the largest amount of the materials in science, are entitled to make their language the main media and force others to follow the trend. In the post-medieval world, English has been the language of science, and teaching the English of science has become an extensive business. It is technically called EAP (English for academic purposes) or ESP (English for Specific Purposes).

ESP is a major activity around the world today. It is an enterprise involving education, training and practice, and drawing upon three major realms of knowledge: language, pedagogy and the students'/ participants' special areas of interest. The study of language for specific purposes has a long and varied history. In recent years, the focus of research and curriculum development has been upon English, as it has gained ascendancy in international science, technology and trade. As TESOL passes its third quarter century, the demand for English for specific purposes (e.g. English for science and technology, English for business, vocational ESL) continues to increase and expand throughout the world.

As Robertson points out, for too long ESP has remained in the shadows of the Second Language Acquisition field and the never- ending circuit of SLA conferences across the world that, as many note, reinvent the wheel each time. Now ESP practitioners are finding their role has become critical as the business world is expecting and demanding graduates to not only speak English, but to be conversant in Business English and the other specialized fields of ESP [13].

Researches and studies conducted on the assessment of ESP effectiveness and usefulness as opposed to English for general purposes [20]; the degree of specificity in ESP courses [3]; ESP lexicon Commonality of language [16]; conjunction words in ESP [4] and ESP methodology [19] suggest a growing demand for ESP courses.

Despite the development of so many ESP courses and textbooks all around the world, the position of ESP as an effective way of satisfying learners' needs is still a controversial issue. The methodology in ESP, the evaluation of ESP learners, and the relationship between general proficiency and ESP knowledge are matters yet to be explored. The latter is a question obsessing the minds of many ESP teachers.

\section{Statement of the problem}

Considering the condition of ESP courses held in Iranian universities, we come to see that the system lacks a disciplined basis upon which a comprehensive program for syllabus design and evaluation may be developed. ESP texts which are taught are nothing but a (random) selection of some technical texts related to the field plus a series of comprehension 
questions and vocabulary exercises. The instructors never consult with specialists in that particular field to grasp the essential needs of the students. The result is the student's distaste of the course and his feeling handicapped when put in a real ESP situation.

Back to the title of our research, an interesting question in this regard is "is there any relationship between students' general proficiency and their achievement in ESP?" In other words, what is the extent to which we can rely on the students' general ability in English in order to build an ESP course upon it? In some universities, General English courses are held for students who perform weakly on their entrance examination. Should such courses be of a general nature or should they lend themselves to specific areas related to the students' field of study just from the beginning?

ESP should be seen simply as an 'approach' to teaching, or what Dudley-Evans describes as an 'attitude of mind' [6]. This is a similar conclusion to that made by Hutchinson and waters who state, "ESP is an approach to language teaching in which all decisions as to content and method are based on the learner's reason for learning" [9].

If we agree with this definition, we begin to see how broad ESP really is. In fact, one may ask 'What is the difference between the ESP and General English approach?' Hutchinson and waters answer this quite simply, "in theory nothing, in practice a great deal” [9]. When their book was written, of course, the last statement was quite true. At the time, teachers of General English courses, while acknowledging that students had a specific purpose for studying English, would rarely conduct a needs analysis to find out what was necessary to actually achieve it. Teachers nowadays, however, are much more aware of the importance of needs analysis, and certainly material writers think very carefully about the goals of learners at all stages of material production. Perhaps this demonstrates the influence that the ESP approach has had on English teaching in general. Clearly the line between where General English courses stop and ESP courses start has become very vague indeed.

Rather ironically, while many General English teachers can be described as using an ESP approach, basing their syllabi on a learner needs analysis and their own specialist knowledge of using English for real communication, it is the majority of so-called ESP teachers that are using an approach furthest from that described above. Instead of conducting interviews with specialists in the field, analyzing the language that is required in the profession, or even conducting students' needs analysis, many ESP teachers have become slaves of the published textbooks available, unable to evaluate their suitability based on personal experience, and unwilling to do the necessary analysis of difficult specialist texts to verify their contents [2].

The present study is aimed to unravel the relationship (if any) between students' general proficiency and their achievement in an ESP course. It is also supposed to measure the amount of correlation between different components of general proficiency and those of an ESP test.

A study of the present nature can be helpful in bringing to the attention of ESP practitioners- as named by Robinson [15] - some latest views and developments in the field of ESP so that they can gradually give up old strategies. It may also prove useful in finding proper ways of preparing students for their future ESP courses. The study will, hopefully, shed some light on evaluation procedures of ESP learners. Finally, course designers and textbook developers should have an understanding of the relationship between General English and ESP for the sake of which this research may prove to be helpful background

\section{What is ESP?}

ESP requires the careful research of pedagogical materials and activities for an identifiable group of adult learners within a specific learning context. Categories of ESP include various academic Englishes, e.g. English for science and technology, English for graduate teaching assistants, and General English for academic purposes, in addition to a number of occupational Englishes, e.g. English for business, and vocational ESL. Peter Strevens (cited in [6]), who throughout his life was instrumental in explaining and developing the movement, provided this extended definition and list of claims:

"A definition of ESP needs to distinguish between four absolute and two variable characteristics:

I) Absolute characteristics:

ESP consists of language teaching which is:

- designed to meet specified needs of the learner

- related in content (i.e. in its themes and topics) to particular disciplines, occupations and activities

- centered on the language appropriate to those activities in syntax, lexis, discourse, semantics, etc., and analysis of this discourse

- in contact with "General English”

II) Variable characteristics:

ESP may be, but is not necessarily:

- restricted as to the language skills to be learned (e.g. reading only) 
- not taught according to pre-ordained methodology

III). Claims: ESP claims to be:

- focused on the learner's needs, wastes no time

- relevant to the learner

- $\quad$ successful in imparting learning

- more cost-effective than 'General English'. ”

\subsection{Development of ESP}

It was mentioned earlier that one major development which contributed to the emergence of ESP was the fact that language education focused on the learners' needs. Considering the fact that learners in different fields had different needs, the field of ESP had to provide diverse courses for various groups of learners. Consequently, ESP had to be divided into different branches [7]. Strevens formulated a taxonomy in which ESP is divided into two major branches: EST (English for science and technology) and English for other purposes. The former is the most prestigious development in ESP [14] and in some countries, in fact, ESP means EST [7]. The latter category includes English for occupational purposes (EOP) and English for educational purposes (EEP).

As far as the development of ESP is concerned, Farhady states that there are inconsistent views with regard to both theory and practice. He attributes these discrepancies to the fact that ESP has been treated independently of the evolutions in language education [7]. However, he states that a general trend of developments can be identified in ESP. These developments can be classified into three eras or generations of "register analysis", "syntactic analysis", and" discourse analysis”.

\subsection{A learning centered approach}

Hutchinson and Waters argue that three motives forced the development of ESP, namely 1) attention to learners' needs, 2) new ideas about language, and 3) new ideas about learning. It should be noted that in its subsequent development, however, scant attention was paid to the last of these three forces - learning. A truly valid approach to ESP must be based on an understanding of the process of language learning [9].

It is impossible to deal adequately with methodology in a paper. Two important points, however, should be emphasized here:

a) There is nothing specific about ESP teaching methodology. The principles which underlie good ESP methodology are the same as those that underlie sound ELT methodology in general. Similarly, at the level of techniques, the ESP teacher can learn a lot from General English practice. The teacher who has come to ESP from General English need not think that a whole new methodology must be learned. The classroom skills and techniques acquired in General English teaching can be usefully employed in the ESP classroom.

b) What happens in the classroom is not just an afterthought to be grafted on to ready-made materials and syllabuses. The activities in the classroom should feedback to all the other stages in the course design. If you can create a useful activity by changing a text, change it. It is the activity that counts.

\subsection{ESP Evaluation}

Another characteristic is assessment. As Robinson has stated, "a component of ESP courses which has not yet been fully developed is that of testing and evaluation. Indeed, some proponents of ESP claim that testing is inappropriate" [14].

Tests for general purpose English are typically norm-referenced, whereas those for ESP are typically criterion-referenced. The attractions of criterionreferenced approach are obvious. Skehen has reported that it is anchored in external factors, as is appropriate for any test of ESP, and makes a statement about what the candidate can do with language, rather than about how well he can take a test. In addition, there are no problems with interpretation, since the only decision involved is whether a candidate passes or fails, and a pass means that the job involved, whatever it is, can be done.

Theoretically, an ESP test would consist of performance in a real life situation. This is not normally practicable, so what is more common is simulated real-life performance. In any case, "the main problem is to establish the major dimensions of language performance in ESP contexts and to elucidate the important language constructs that are involved"

Widdowson [19] and others would appear to agree with Ewer that ESP is 'task- oriented' and thus a student on an ESP course is tested when he is asked to perform the task for which the ESP course has prepared him (cited in [14]). Swales's definition of a task for ESP includes three specific ESP factors: (1) the fact that the activities are goal-directed; (2) the requirement that the activities are related to the acquisition of genre skills; and (3) that they are appropriate to a foreseen or emerging sociorhetorical situation [18]. Swales has also demonstrated that "one of the relevant conditions of language use and learning is the interplay of text and task, whereby difficulty in the former is balanced by simplicity in the latter?' 
Other ESP course directors, for example, Higgens and Davis have found "the need for more explicit tests” (cited in [14]). More elaborate explanation comes from Hutchinson and Waters' recognition of three basic types of assessment: “1. Placement tests, 2. Achievement tests, and 3. Proficiency tests” [9]. Placement tests are used to 'place' learners in the ESP course most suited to their needs. It should show not just what the learner lacks, but also what potential for learning can be exploited in the ESP course. Achievement tests evaluate how well the learner is keeping up with the syllabus. And proficiency tests assess whether or not the student can cope with the demands of a particular situation, for example, study at a university or reading technical manuals. Hutchinson and Waters have more thoroughly described the situation:

The 'what' of ESP course evaluation is concerned with assessing the extent to which the course satisfies two kinds of learners' needs: their needs as language learners and their needs as language users. The 'how' of your test will depend on what suits your teaching situation best [9].

\section{Differences between ESP and GE (General English)}

Previously, the aim of language was mastering the so-called skills, i.e., speaking, listening, reading, and writing. These purposes were seen as relating to general education at the primary and secondary levels [1]. In recent years, however, ESP has emerged as a particular subdivision of general activity of Teaching of English to the Speakers of other Languages. In this regard, language education deals with teaching General English (GE) which according is content independent or good for all learners.

However, separating ESP from GE is a controversial issue. Some authorities believe that such a distinction is to some extent invalid.

The opponents of the ESP and GE separation believe that there are no appreciated structural differences between Special English and General English. Furthermore, the proponents of this view consider ESP as a variation of GE which has samples taken from subjects for specific purposes [12]. In this regard, some specialists believe that ESP essentially serves the needs of non-native speakers of English. Therefore, it is one of the branches of teaching English as a foreign language.

Early research in this field hypothesized that the major differences between ESP and GE lies in the technicality of lexicon [7]. Some other scholars made a distinction between GE and ESP in other ways.
Strevens believes that ESP contrasts with General English which can be referred to as "English of the exam". He further pointed out that the nature of ESP depends on the needs of the learners who experience those needs [17]. In this regard, Hutchinson and Waters contended that ESP is not a particular kind of language and methodology, nor does it consist of a particular type of material. It is an approach to language teaching which is based on the learner needs [9]. Widdowson believes:

"General purpose English is no less specific and purposeful than ESP. What distinguishes them is the way in which the purpose is defined. ESP is essentially a training operation which enables the learners to cope with defined eventuality in future" [19].

Strevens [17] explained the characteristics of an ESP course which distinguishes it from a GE course as follow:

ESP entails the provision of English language instruction:

- devised to meet the learner's particular needs,

- related in themes and topics to designated occupation: or areas of study,

- $\quad$ selective (i.e. not 'general) as to content,

- when indicated, restricted as to the language 'skills' included.

Robinson pointed out that an ESP course is purposeful and aims at successful performance of occupational and educational roles. It is designed, therefore, on the basis of students' needs and should be tailor -made [14].

Based on the views mentioned above, it is not always possible to separate ESP from GE. However, there are some characteristics which are usually associated with ESP rather than GE. Rigid specificity of purpose is the most important feature of ESP. That is, ESP is designed to "train" learners to cope with certain predetermined requirements. The particular needs of the learners are usually those imposed by their occupations or areas of study. Also, according to Farhady, ESP is associated with later stages of language learning, while GE is associated with earlier ones. That is, GE instruction prepares learner for ESP instruction [7].

In their comparison between GE teacher and ESP teacher, Zhu and Liao state that both GE and ESP teacher should be able to identify the current language level of the learner and to select materials and set tasks that are appropriate in level as well as in context. They also need to be able to set course objectives and devise course program. In order to achieve this it is essential for the teacher to have an in-depth knowledge of the language system in terms of skills functions, structures and vocabulary [20]. 


\section{Research Questions}

We had two kinds of subjects; English majors and non-English majors i.e. the students of engineering. An educated guess was that the performance of these two groups could not be similar in GE and ESP tests (and this guess was supported in the actual results we got). Therefore, the following research questions were posed in such a way as to account for separate analyses for the two groups.

1. Is there any relationship between undergraduate (Engineering) students' General English and their ESP achievements?

2. Is there any relationship between undergraduate English majors' General English and their ESP achievement?

3. Is there any relationship between the score of the students of Engineering on different components of a General English test and those of an ESP test?

The following null hypotheses were formulated.

$\mathrm{H}_{0} 1$ There is no significant relationship $(\mathrm{P}<0.05)$ between the undergraduate (Engineering) students' General English and ESP.

$\mathrm{H}_{0} 2$ There is no relationship $(\mathrm{p}<0.05)$ between undergraduate English majors' General English and their ESP.

$\mathrm{H}_{0} 3$ There is no significant relationship $(\mathrm{P}<0.05)$ between the score of the students of Engineering on different components of a General English test and those of an ESP test.

\section{Method}

\subsection{Subjects}

Two groups of subjects took part in this study. There were 59 students (freshmen and sophomores) studying Engineering at Ferdowsi University in Mashhad. They were passing an ESP course called "English for the students of Engineering". Also, 41 senior English majors from the Islamic Azad University, Quchan Branch participated in this study.

\subsection{Instrumentation}

6.2.1. General English Tests. The researcher had already compiled a discrete-point test of general proficiency within the format of a TOEFL. Due to practical problems we could not include listening and speaking sections in the test.

This test was validated against an original TOEFL with 40 students in Islamic Azad University, Quchan Branch. The Karl Pearson correlational analysis was done and a coefficient of 0.69 resulted. Since we could claim a criterion- related validity for our test, we used it as an instrument to measure the general English knowledge of the students of Engineering in this research.

6.2.2. General English Test for English Majors The above mentioned test seemed to be quite simple for English-majors and, therefore, not suitable for their level. To test the General English knowledge of these students, an original TOEFL was used. Again the researcher had to ignore listening section of the test. This test was given to 41 English-majors of Islamic Azad University, Quchan Branch.

6.2.3. ESP Tests. The ESP test for the students of Engineering was actually a final achievement test which was based on the material they had covered during the term. This test was prepared by the ESP teacher and was practically out of the researcher's control. It, therefore, had to be validated. Davies has argued forcefully that external (i.e. criterion-related) validation based on data is always to be preferred. To make sure that the ESP test was valid, a Nelson English Test version C350 was given to these students [5].

Although there were suggestions that Nelson is not a highly authentic test, and a Michigan Test may be more credible, the level of the testees did not allow a difficult test such as Michigan. Of the 59 students who had taken the main test, 43 took part in the criterion test i.e. Nelson Test. The correlational analysis of the results showed a coefficient of 0.90 , hence a high criterion-validity for the ESP test.

We also needed an ESP test for the English majors. This specific English test does not include vocabulary or grammar items. But since it includes reading, comprehending and analyzing specialized texts written in English (for non-native speakers), it is still a kind of ESP.

In this research, we chose the latest version of MA Entrance Examination (specialized English part) for TEFL students which is annually prepared and administered by the Ministry of Science, Research, \& Technology. This is a test which is based on the specialized material in TEFL the student had covered during their BA period. Since this test is prepared by highly experienced experts in TEFL who are quite familiar with testing theories and procedures, it was felt to be an appropriate test.

\subsection{Procedure}

As mentioned before, we had two groups of subjects in this research: 59 students (freshmen and sophomores) of Engineering, and 41 students majoring in English. The first group took a test of 
General English sometimes toward the middle of the term. After a week, they took a Nelson Test as a criterion for validation of ESP test. At the end of the term, they were given a final achievement ESP test.

The second group was given a TOEFL test as a measure for their General English knowledge. After a week, the ESP test was administered to this group. Since this test was based on their overall knowledge of their field, the time of the administration was not of any significance here.

\subsection{Data Analysis}

The main analysis which directly relates with the three research questions is correlation. We, therefore, ran a correlation between the two sets of scores for each group plus three correlations between components of the two tests (i.e. grammar, vocabulary, and reading).

In order to further explore the nature of the relationship between students' General English and their ESP knowledge, T-tests were conducted between total scores and componential scores of the two tests for each group. The software used for all the above analyses was SPSS for Windows.

\section{Results and Discussion}

\subsection{Results of the Analysis for Hypothesis 1}

In order to test this hypothesis, we ran Karl Person correlation from SPSS for Windows. The following table resulted.

Table 1. Correlation coefficient of GE \& ESP in students of engineering

\begin{tabular}{|c|c|c|}
\hline & ESP & GE \\
\hline \multirow{2}{*}{ ESP } & 1.000 & .8760 \\
\cline { 2 - 3 } & $(59)$ & $(59)$ \\
\hline
\end{tabular}

$\mathrm{P}=0.00$

The correlation coefficient of .87 suggests a high and positive correlation between the General English knowledge of the students and their ESP achievement. The first null hypothesis is, therefore, rejected since there does exist a relationship and this relationship is highly positive.

It might be said that this result was, to some extent, predictable; anyhow, General English and ESP are both English knowledge and success in one means success in the other. We should be reminded, however, that correlations by no means imply a sense of cause-and-effect logic. Is capability in General English as a background a cause for further success in ESP? Or has the constant working with English through ESP tasks improved the subjects' general English? Or else, something like overall academic success or intelligence, etc. has caused success (or the lack thereof) in these two traits.

Unlike Strevens who believes that General English is 'English for the exam,' here, we may call ESP as 'the English for the exam'. The non-English majors in this study were passing an ESP course which was part of their educational career. They were much more motivated in taking the ESP test than they were in taking the general test (which they knew was an extracurricular test with no effect on their final marks. So we see that the relationship between General English and ESP depends on lots of factors only a few of which are controlled in this study.

\subsection{Results of the analysis for Hypothesis 2}

The reason we separated English majors from non-English majors was that the former worked exclusively with the English language. They learned General English: they, then, used their general English to learn specific subjects in English (i.e. ESP). In other words, they both majored and minored in English. Karl Pearson correlation from SPSS for Windows was run for the result of General English (TOEFL) and ESP (TEFL) tests of this group, and the following table resulted.

Table 2. Correlation Coefficient of GE and E SP for English Majors

\begin{tabular}{|c|c|c|}
\hline & ESP & GE \\
\hline \multirow{2}{*}{ ESP } & 1.000 & .8556 \\
\cline { 2 - 3 } & $(38)$ & $(38)$ \\
\hline
\end{tabular}

The correlation coefficient of .85 indicates that there exists a relationship between the English majors' General English and their ESP achievement. It further indicated that this relationship is highly positive. The second null hypothesis is, thereby, rejected.

Here again, the results should be interpreted with caution. The existence of this relationship does not imply a cause-and-effect relationship between General English and ESP in these subjects. Is it because they have learnt general English that they can comprehend their Special English? Or is it because all their special subjects are presented in English that their general English has been positively affected?

\subsection{Results of the Analysis for Hypothesis 3}

In addition to calculating the total scores of the subjects, their componential scores for Grammar, 
Vocabulary, and Reading Comprehension were also calculated. Since the number of items in each section was different, we converted the raw scores to percentage. Three correlations were run for these components of the two tests and the following tables resulted.

Table 3. Correlation Coefficient of GE Grammar \& ESP Grammar in Students of Engineering

\begin{tabular}{|c|c|c|}
\hline & ESP Grammar & GE Grammar \\
\hline \multirow{2}{*}{ ESP Grammar } & 1.000 & .7478 \\
\cline { 2 - 3 } & $(59)$ & $(59)$ \\
\hline
\end{tabular}

$\mathrm{P}=0.00$

Table 4. Correlation Coefficient of GE Vocabulary \& ESP Vocabulary in Students of Engineering

\begin{tabular}{|c|c|c|}
\hline & $\begin{array}{c}\text { ESP } \\
\text { Vocabulary }\end{array}$ & GE Vocabulary \\
\hline ESP Vocabulary & 1.000 & .7060 \\
\cline { 2 - 3 } & $(59)$ & $(59)$ \\
\hline
\end{tabular}

$\mathrm{P}=0.00$

Table 5. Correlation Coefficient of GE Reading \& ESP Reading in the students of Engineering

\begin{tabular}{|c|c|c|}
\hline & ESP Reading & GE Reading \\
\hline ESP Reading & 1.000 & .7761 \\
\cline { 2 - 3 } & $(59)$ & $(59)$ \\
\hline
\end{tabular}

The correlation coefficients of .74 for Grammar, .70 for vocabulary, and .77 for Reading show that all the components of each test have a rather high positive correlation with their equivalent in the other test. This Correlation is higher in Reading, lower in Grammar, and the lowest in Vocabulary. Therefore, the third null hypothesis is also rejected.

As Dudley-Evans has put it, there are many misconceptions about the role of grammar in ESP teaching, and indeed, it is often said that ESP teaching is not concerned with grammar. He further suggests that although the role of grammar is not central, it is incorrect to totally ignore it in the ESP teaching program [6]. Dudley-Evans' claim is properly supported in this study. A coefficient of .74 shows that a good mastery of grammar for ESP students helps them in their higher ESP achievements.

In discussing the teaching of ESP, it has often been said (for example Hutchinson and Waters [9]) that the teaching of technical vocabulary is not the responsibility of the EAP teacher and that priority should be given to the teaching of 'semi-technical 'or 'core vocabulary'. Dudley-Evans believes that this idea oversimplifies the true situation. He, therefore, puts more emphasis on technical vocabulary. The findings of this study (while not rejecting DudleyEvans' suggestions,) well supports the former claim made by people like Hutchinson and Waters. Those students who had a good command in general nontechnical vocabulary, well succeeded in ESP vocabulary items. Although this correlation was the lowest among the three components, it is still considered a rather significant correlation.

The coefficient correlation for reading was the highest among the three components (.77). Of course, it should be noted that reading is actually a language skill, not a language component. In this receptive language skill use is made of such language components as grammar and vocabulary. Therefore, this correlation is not free from the effect of the first two correlations. In order to justify the above results, we may have a look at the position and significance of Reading in ESP.

McDonough has argued that where ESP has developed alongside the research base of language teaching in general, most researchers have covered language skills, especially reading. Reading purpose is a central concern of ESP [8]. Bloor has put forward the point that critical reading is essential for effective participation in an academic setting. Lutoslawska believed that students in technical colleges, who can devote only a limited time to learning a language, should use that time to develop the only skill they really need: an ability to read the language. He has maintained that the reality of our situation requires that we prepared the students within a very limited time to read the scientific prose [11]. Savory has further noted: "Scientific knowledge is spread almost entirely by the printed word which is read by the learner, it never depends wholly on the spoken word which was heard by the listener." (cited in[11]).

From the above discussion we could see that most ESP students choose 'Reading' as the skill they need most. They devote of their time and effort to develop this basic language skill. Therefore a high correlation between General English Reading and ESP Reading seems to be the natural outcome of this focus on reading in general.

\subsection{Additional Analyses}

For the students of engineering, we did four paired sample t-tests; one between their total scores and three between their componential scores. If we consider a .05 level of significance for each of these t-tests, the overall probability for error will be 0.05 multiplied by 4 which equals 0.2 . This is what kinnear and Colin call per family type I error [10]. To achieve significance, therefore, each t-test must show significance beyond (sometimes well beyond) the 0.05 level following a one-factor ANOVA. In this case the per family type I error rate must be divided 
by the number of possible pairs ( $c$ ) that can be drawn from any array of $K$ means, which is given by

$$
\mathrm{c}=\frac{\mathrm{k} !}{2 !(\mathrm{k}-2) !} \text {. }
$$

To attain this level of significance, we first ran a one-way repeated measure ANOVA taking both total and componential scores of the two tests of Engineering students as dependent variables. The following table shows the result of this ANOVA.

Table 6. Analysis of Variance for Total and Componential scores of ESP \& GE Tests in students of Engineering

\begin{tabular}{|l|c|c|c|c|c|}
\hline $\begin{array}{l}\text { Source of } \\
\text { Variation }\end{array}$ & SS & DF & MS & F & $\begin{array}{c}\text { F } \\
\text { Critical }\end{array}$ \\
\hline $\begin{array}{l}\text { Within }+ \\
\text { Residual }\end{array}$ & 31464.82 & 406 & 77.50 & & \\
\hline Factor 1 & 25848.43 & 7 & 3692.63 & 47.65 & 2.20 \\
\hline
\end{tabular}

$\mathrm{DF}$ between $=\mathrm{k}-1=8-1=7$

DF within $=\mathrm{N}-\mathrm{K}=59-8=51$

The observed $\mathrm{F}$ at 0.05 level of significance is higher than F-critical, hence, the significance of $\mathrm{F}$.

Know, we can determine the level of significance for our t-tests by using the formula mentioned above.

$$
\begin{aligned}
\mathrm{C} & =\frac{8 !}{2 !(8-2) !}=\frac{56}{2}=28 \\
\mathrm{P}=\frac{0.05}{28} & =0.001
\end{aligned}
$$

Hence, the level of significance for our t-tests should be considered as 0.001 .

7.4.1. T-test for GE and ESP in Students of Engineering. The two sets of scores of students of engineering were put in SPSS for Windows and the paired sample t-test was run. The following table resulted.

Table 7. T-test for GE \& ESP in the students of Engineering

\begin{tabular}{|l|l|l|l|l|l|l|}
\hline Variable & $\begin{array}{l}\text { Number } \\
\text { of pairs }\end{array}$ & corr & $\begin{array}{l}2- \\
\text { tail } \\
\text { sig }\end{array}$ & Mean & SD & $\begin{array}{l}\text { SE of } \\
\text { Mean }\end{array}$ \\
\hline ESP & & & & 52.59 & 15.08 & 1.96 \\
\hline & 59 & .786 & .05 & & & \\
\hline GE & & & & 43.69 & 12.76 & 1.66 \\
\hline
\end{tabular}

\begin{tabular}{|l|l|l|l|l|l|l|}
\hline \multicolumn{2}{|c|}{ Paired Differences } & \multicolumn{4}{|l|}{} \\
\hline Mean & SD & $\begin{array}{l}\text { SE of } \\
\text { Mean }\end{array}$ & t-value & Df & $\begin{array}{l}\text { t- } \\
\text { critical }\end{array}$ & $\begin{array}{l}\text {-tail } \\
\text { sig }\end{array}$ \\
\hline 8.8983 & 7.286 & .949 & 9.38 & 58 & 3.551 & 0.00 \\
\hline
\end{tabular}

As the table suggests, at the df of 58 and $\mathrm{p}$ of 0.001 level of significance, the t-value is much greater than the t-critical. We could, therefore, claim that, in total, the students of Engineering performed significantly better in their ESP test than in General English test.

Before we discuss and justify this finding, we will do the same analysis for different components of the two tests as well as a t-test for English majors

7.4.2. Componential T-tests. The students' scores on Grammar, Vocabulary, and Reading sections of the two tests were compared with each other and the

\begin{tabular}{|c|c|c|c|c|c|c|c|c|}
\hline Variable & $\begin{array}{l}\text { Number } \\
\text { of pairs }\end{array}$ & corr & $\begin{array}{l}- \\
\text { tail } \\
\text { sig }\end{array}$ & $\mathrm{Me}$ & & SD & \multicolumn{2}{|c|}{$\begin{array}{l}\text { SE of } \\
\text { Mean }\end{array}$} \\
\hline $\begin{array}{l}\text { ESP } \\
\text { Gram }\end{array}$ & & & & \multicolumn{2}{|c|}{66.06} & 18.66 & \multicolumn{2}{|c|}{2.42} \\
\hline & 59 & .784 & .05 & & & & & \\
\hline GE Gram & & & & \multicolumn{2}{|c|}{54.01} & 17.96 & \multicolumn{2}{|c|}{2.33} \\
\hline \multicolumn{9}{|c|}{ Paired Differences } \\
\hline Mean & SD & $\begin{array}{l}\text { SE } \quad \\
\text { Mean }\end{array}$ & \multicolumn{2}{|c|}{ t-value } & $\mathrm{df}$ & \multicolumn{2}{|c|}{ t-critical } & $\begin{array}{l}\text { 2-tail } \\
\text { sig }\end{array}$ \\
\hline 12.0508 & 13.020 & 1.695 & 7.1. & & 58 & 3.55 & & 0.00 \\
\hline
\end{tabular}
following tables resulted.

Table 8. T-test: GE Gram. \& ESP Grammar in the students of Engineering

Table 9. T-test: GE voc. \& ESP voc. in students of Engineering

\begin{tabular}{|l|l|l|l|l|l|l|}
\hline Variable & $\begin{array}{l}\text { Number } \\
\text { of pairs }\end{array}$ & corr & $\begin{array}{l}2- \\
\text { tail } \\
\text { sig }\end{array}$ & Mean & SD & SE of Mean \\
\hline ESP Voc & & & & 58.27 & 20.25 & 2.63 \\
\hline & 59 & .706 & .05 & & & \\
\hline GE Voc & & & & 48.88 & 14.78 & 1.62 \\
\hline Paired Differences & SD & $\begin{array}{l}\text { SE of } \\
\text { Mean }\end{array}$ & t-value & df & t-critical & $\begin{array}{l}\text { 2-tail } \\
\text { sig }\end{array}$ \\
\hline Mean & SD & & & & \\
\hline
\end{tabular}

Table 10. T-test: GE Reading \& ESP Reading in the students of Engineering

\begin{tabular}{|l|l|l|l|l|l|l|}
\hline Variable & $\begin{array}{l}\text { Number } \\
\text { of pairs }\end{array}$ & corr & $\begin{array}{l}2- \\
\text { tail } \\
\text { sig }\end{array}$ & Mean & SD & $\begin{array}{l}\text { SE of } \\
\text { Mean }\end{array}$ \\
\hline ESP Read & & & & 64.84 & 19.39 & 2.52 \\
\hline & 59 & .776 & .05 & & & \\
\hline GE Read & & & & 62.03 & 23.54 & 3.06 \\
\hline Paired Differences & $\begin{array}{l}\text { SE of } \\
\text { Mean }\end{array}$ & $\begin{array}{l}\text { t- } \\
\text { value }\end{array}$ & df & t-critical & $\begin{array}{l}\text { 2-tail } \\
\text { sig }\end{array}$ \\
\hline Mean & SD & & & & & \\
\hline
\end{tabular}

The above tables show that the subjects performed significantly better in ESP Grammar than in GE Grammar. The subjects performed significantly better in ESP Vocabulary than in GE Vocabulary. Moreover, the subject performed better in ESP Reading than in GE Reading, but the difference was not significant. 


\subsubsection{T-test for GE and ESP in English Majors}

Table 11. T-test: GE \& ESP in English majors

\begin{tabular}{|l|l|l|l|l|l|l|}
\hline Variable & $\begin{array}{l}\text { Number } \\
\text { of pairs }\end{array}$ & corr & $\begin{array}{l}2- \\
\text { tail } \\
\text { sig }\end{array}$ & Mean & SD & $\begin{array}{l}\text { SE of } \\
\text { Mean }\end{array}$ \\
\hline ESP & & & & 39.18 & 15.78 & 2.56 \\
\hline & 38 & .924 & .05 & & & \\
\hline GE & \multicolumn{7}{|l|}{} \\
\hline Paired Differences & & & 45.63 & 15.22 & 2.47 \\
\hline Mean & SD & $\begin{array}{l}\text { SE of } \\
\text { Mean }\end{array}$ & $\begin{array}{l}\text { t- } \\
\text { value }\end{array}$ & df & t-critical & $\begin{array}{l}\text { 2-tail } \\
\text { sig }\end{array}$ \\
\hline
\end{tabular}

The table suggests that English majors (unlike non-English majors) performed significantly better in their General English test than in their ESP.

\section{Discussion}

The above findings are interesting since they indicate an important difference between English majors and non-English majors, a difference about which the main analysis revealed nothing. The main analysis showed that the null hypotheses for both groups were rejected. This may mislead the reader at the first sight so that he may believe that the two groups are similar in this respect and that there is no reason to separate them. The additional analysis, however, alarms us that although the performance of both groups in GE highly correlated with their scores in ESP, the English majors performed better in GE while non-English majors performed better in ESP.

As a TEFL major, the researcher could easily understand the essence of this difference. NonEnglish majors are far from their experience with GE training. Their education in General English was limited to their high school period or some institutional classes. They are now in an ESP situation. They need to and are motivated to learn Specific Language of their field of study and do not feel obliged to work with General English. Naturally, what is fresh in their minds is ESP and it would have been a matter of surprise if the reverse had occurred.

But English majors have a different story. Their academic success depends, to a great extent, on their general proficiency (fluency \& accuracy). Although they learn Specific subjects in English, General English remains an important (if not the most important) part of their curriculum. They are constantly in contact with General English by means of Reading books, listening to radio, or watching films in English. As a result they are often better at general English than at ESP.

Tables 8, 9 and 10 show that students of Engineering performed better in all components of their ESP test than in those of the GE test, but this difference was not significant in Reading. The justification for this finding may be eased if we remember that reading is the first and the foremost language skill that learners feel they need to acquire. They put most of their effort and time on developing this basic skill. The learners may choose different strategies to develop their reading capabilities, but any piece of activity in this regard affects the reading skill in general. As a result, we should expect that the differences be insignificant when most of the subjects have a shared interest in developing one skill.

\section{Conclusion}

This research aimed at determining the relationship between subjects' General English and their ESP achievement. It was also tried that the nature of this relationship be dissected. The findings of this chapter confirmed the existence of a highly positive correlation between GE and ESP (total and componential) scores of subjects.

Additional analyses also showed that the nature of this correlation was not the same in English and non-English majors. While English majors outperformed in their General English test, nonEnglish majors did better in their ESP test. The justification given here was a matter of exclusiveness and inclusiveness. While the non-English majors exclusively work with ESP, English majors inclusively work with General English as well as with ESP.

\section{Implications}

The results of this study may be helpful for ESP teachers from different perspectives. Firstly, they can see that a General English test may well predict the learners' future success in ESP. At the beginning of an ESP course, the learners have little knowledge of ESP and the teacher cannot give them an ESP pretest. But since the correlation between the two is established in this study, he can use a valid GE test as his pre-test. Since the correlation is also established between different components, a GE test may also be of diagnostic value for the ESP teacher.

Secondly, the ESP teacher can, based on the findings of this study, accommodate some GE practice in his syllabus as a source of helpful device for the development of the learners' ESP. He should no more consider working with GE as a deviation from the objectives of the course. Whenever the learners cannot get a point which is introduced in an ESP context, the teacher may, with no worry, put the point in a GE context and, then, teach it. 
As it was mentioned in the first chapter of this study, ESP courses are still immature in our country. They are not based on a well-defined theory of ESP and it is not clear how different they are from GE courses. Moreover, textbooks are naively prepared only as a selection of some technical texts plus several practices. Studies like the present one are particularly intended to bring to the attention of these ESP practitioners some latest views and findings about the 'what' and 'how' of ESP.

The findings of this study implies that course designers and material developers should give up their old tradition of 'being just specific to teach specific' and that they can accommodate more GE especially at earlier stages. They may define a threshold level of GE upon which an ESP course could be built.

\section{References}

[1] Allen, J. P. B., \& Widdowson, H. G. (1974). 'Teaching the communicative use of English' International Review of Applied Linguistics, XII (I).

[2] Anthony, L. (1997) 'ESP: What does it mean?’ ON CUE.http://interserver.miyazakimed.ac.jp/ cue/pc/anthony. htm Retreived April 6, 2000, from the World Wide Web.

[3] Cianflone, Eugenio. (2010) 'What Degree of Specificity for ESP Courses in EFL Contexts?' Scripta Manent. Published by SDUTS, 5 (1-2) 3-8.

[4] Cohen, A., H. Glasman, P.R. Rosenbaum-Cohen, J. Ferrara, \& J. Fine (1986) 'Reading English for specialized purposes. Discourse analysis and the use of student informants’ In Carrell, Devine, \& Eskey, 1986, pp.150-63.

[5] Davies, F. (1988) 'Designing a writing syllabus in English for academic purposes: Process and product' ELT Documents: 129.

[6] Dudley-Evans, T. \& ST John M. J. (1998) Developments in English for Specific Purpose, Cambridge University Press, Cambridge.

[7] Farhady, H. (1994) 'On the specificity of purpose in ESP' In Proceedings of the $2^{\text {nd }}$ conference on theoretical and applied linguistics, Tehran (pp.63-82).

[8] Hudson, T. (1991) 'A content comprehension approach to reading English for science and technology' TESOL QUARTERLY, 25(1), pp. 77-104.

[9] Hutchinson, T. \& Waters, A. (1987) English for specific purposes: A learning centered approach, Cambridge University Press, Cambridge.

[10] Kinnear, P. R. \& Colin D. G. (1999) SPSS for Windows Made Simple, UK. Psychology Press 18(2), pp. 121-138.
[11] Lutoslawska, J. (1 975) 'Reading technical English' Forum, XII I (3\&4), 247-249.

[12] Mackay, R. \& Mountford, A.J. (1978). English for specific purposes: A case study approach. London: Longman.

[13] Robertson, P. \& Nunn, R. (2010) 'Foreword' The Asian ESP Journal, Special Edition: The 1st Asian ESP Conference, Chonquing University October 2010.

[14] Robinson, P. (1980). ESP (English for specific purposes). Oxford: Pergamon.

[15] Robinson, P.C. (1991). ESP today: A practitioner's guide. London: Prentice Hall.

[16] Selinker, L. (1977). 'Some early observations on EST' In Trimble, Trimble, \& Drobnic (pp.1-8).

[17] Strevens, P. (1980). Teaching English as an International Language: Practice to Principle. Pergamon Press.

[18] Swales, J. (1985). Episodes in ESP, Oxford: Pergamon Press.

[19] Widdowson, H. G. (1998). 'Communication and community: The pragmatics of ESP' English for Specific Purposes, 17, (1), pp. 3-14.

[20] Zhu, Wenzhong \& Fang Liao (2008) 'On Differences between General English Teaching and Business English Teaching' English Language Teaching, Vol. No. 2, pp. 9095 